\title{
The Enforceability of Wa'd Mulzim (Binding Promise) from a Fiqh Perspective: A Critical Analysis of Wa'd Application in Sukūk Contracts
}

\author{
Mohd Fuad Md. Sawari, ${ }^{1}$ Nik Azizu Nik Abdullah, ${ }^{2}$ Mustafa Mat Jubri, ${ }^{3}$ Akhtarzaite Abd. Aziz ${ }^{4}$
}

\begin{abstract}
Wa'd (promise) is a concept that is frequently applied in various Islamic financial products. Although this concept has been used widely in Islamic financial products, as a result of the arising Shari' ah issues, wa 'd especially wa'd mulzim (binding promise) in some contemporary practices towards contracts of Islamic financial products, remains a debatable practice among some Sharī'ah scholars. This research aims to analyse some Shari'ah issues pertaining to the application of the wa'd mulzim in the Islamic finance industry, especially the issue of wa'd mulzim in sukūk contracts, particularly in partnership-based contracts which are sukūk mud̄ārabah, and sukūk mushārakah concepts. Two aspects are particularly emphasized. First, wa'd can be binding in certain conditions, but to legally enforce this concept, there remain disputes and controversial discussions among scholars. Second, this study also discusses the issues of "promise to buy" or "promise to sell" (the asset) at a certain "price" i.e. the price at the same nominal value at which the bond was issued. Hence, this research will try to analyse the opinions of the scholars, certain related fatwas, Shari' 'ah resolutions and guidelines to understand the applicability of the binding promise towards Islamic financial products and ensure that the application of the binding promise is in line with the Shari' 'ah requirements.
\end{abstract}

Keywords: Wa'd, Sukūk, Muḍārabah, Mushārakah, Fiqh

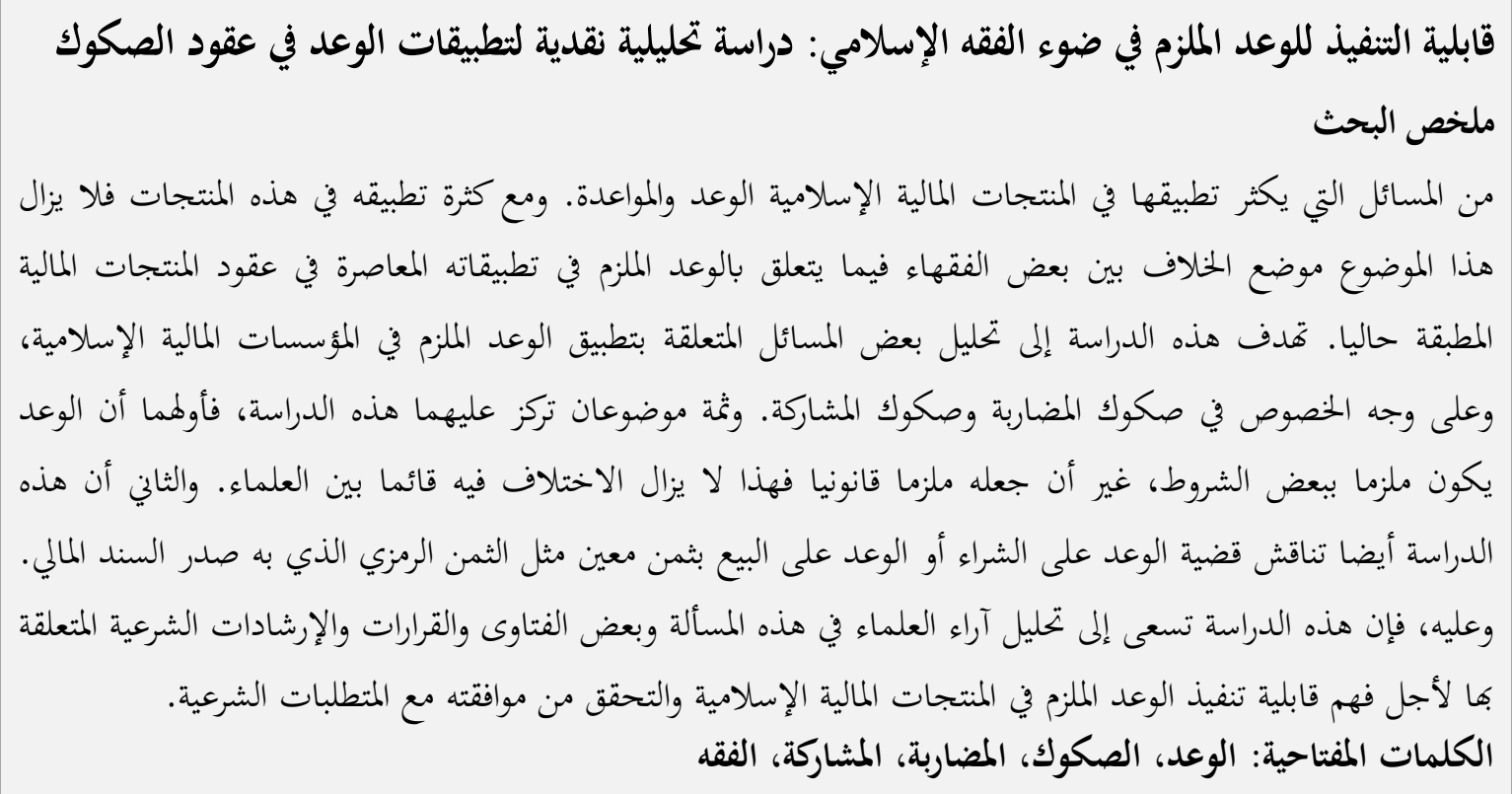

${ }^{1}$ Assist. Professor, Department of Fiqh \& Usul al-Fiqh, International Islamic University Malaysia, (IIUM). sawari@iium.edu.my

${ }^{2}$ Shariah Officer, AmIslamic Bank, Malaysia.azizu-abdullah@ambankgroup.com

${ }^{3}$ Assist. Professor, Department of Fiqh \& Usul al-Fiqh, International Islamic University Malaysia, (IIUM). mussham@iium.edu.my

${ }^{4}$ Assist. Professor, Department of Fiqh \& Usul al-Fiqh, International Islamic University Malaysia, (IIUM). akhtarzaite@iium.edu.my 


\section{Contents}

\section{Introduction}

The Concept of Wa'd from a Sharī'ah

Perspective

Wa'd in Partnership-Based Sukūk Contracts

Wa'd in Sukūk Muḍārabah

Wa'd in Sukūk Mushārakah

Sharī'ah Issues of Wa'd Mulzim in PartnershipBased Sukūk Contracts

Sharī'ah Solutions

Conclusion

References

\section{Introduction}

The Islamic financial industry has been growing continuously ever since the first institution started operating in the early seventies. At present, most Islamic financial services are being provided in almost all parts of the world by different financial institutions, including more well-established conventional institutions which have also started to provide Islamic financial products and services. In this modern era, as the economic market grows to be more competitive, the Islamic financial industry is now facing more challenges and risks arising from its financial operations and transactions. Indeed, it is always important for all financial institutions to explore new standards and techniques to mitigate any possible risk to provide financial services at low risk and thus ensure their survival.

It goes without saying that the fundamental code and overarching principle in guiding the philosophy, principles, and tenets of Islamic finance has always, and will always be, the observance of Sharī'ah. Therefore, it is an obligation on both parties (the Islamic financial institution itself and its conventional counterpart) to ensure that any financial products or services bearing an Islamic name comply with the underlying basis of the practice of Islamic finance. Hence, any new standard, technique, or concept must be carried out in a manner that is in line with the injunctions of Islam, observing the tenets, conditions, and principles espoused by Sharī'ah. Where Sharī'ah compliance is concerned, this new technique will be deemed unusable unless it meets the standards specified by the Sharī'ah.

Pursuant to this need, $w a^{\prime} d$, a classical yet relatively new Sharī'ah concept has been introduced into modern Islamic financial products. Although this concept of $w a^{\prime} d$ has been used primarily alongside murābahah sale by the purchase orderer (murābahah li al-amìr bi alshira ${ }^{6}$ ) since the early days of institutionalized Islamic finance, in recent years, it seems to have gained more popularity and has become one of the new innovative concepts that carries exciting possibilities, as well as having a significant market potential. Indeed, the range of opinion pertaining to the binding-ness of $\mathrm{wa}^{\prime} d$ is varied, but it seems that the view held by the majority of modern scholars is that $w a^{\prime} d$ is binding if it is given with specific conditions.

As a result, it comes with no surprise that in recent years, the concept of binding wa' $d$ has been incorporated in many Islamic financial products. It has been widely applied in lease ending with ownership (ijārah muntahiyah bi altamlīk), Islamic hire-purchase (ijārah thumma albai'), diminishing partnership (mushārakah mutanāqisah), hedging products such as Islamic forward forex, Islamic profit rate and cross 
currency swaps, and various sukūk structures. Apart from its general purpose of risk mitigation, the recourse to $\mathrm{wa}^{\prime} \mathrm{d}$ in these products was also due to its viability as a tool that may serve various other purposes, which include being an alternative to put options and call options in swaps, a tool for liquidity management, an exit mechanism in redeeming sukūk, and as a hedging mechanism in some derivative products (Muhammad, 2011, 2).

In addition, wa'd has lately been considered a major device for Islamic financial institutions to structure many products to replicate and compete with products by their conventional counterparts (Lukman, 2008, 1).

It is a well-established custom in the banking and commerce world that any form of pledge or promise, either mutual or unilateral, made prior to the actual sale and purchase activity, has to be given due respect and is considered as binding.

This is due to the fact that in modern times, with the presence of a competitive financial market as well as ever-changing customers' demands, a bank's role has gradually shifted from merely being a finance intermediary to being a body that directly engages in many instances of transaction, which has undeniably formed a new variety of financial risks for the bank's operation (Abdullah, 2010, 1).

$W a^{\prime} d$ has indeed became one of the new innovative Sharī'ah concepts with exciting possibilities and significant market potential in Islamic finance. Although initial groundwork has been laid on the legality of binding $w a$ ' $d$, it seems there are still gaps in the research available in literature, as this concept has not been adequately covered and developed, and there has been no or relatively few standards legislated purely for its use and applicability by international bodies such as IFSB and AAOIFI (Firoozye, 2009, 6).

Nonetheless, due to its ostensible feasibility, the application of $w a$ ' $d$ in the Islamic financial industry is seen to be immense, or perhaps the applicability of this novel concept has been over-generalized by some parties. Therefore, some scholars, most notably Rafiq alMasri, have outspokenly expressed their concerns and criticisms about the legal enforcement of wa'd, (al-Masri, 2002, 29-32) which has instigated wide deliberation and discussion on the concept.

On this basis, this paper feels that there still is a need to conduct a holistic and extensive study on the concept of $w a^{\prime} d$ to provide a greater understanding of it and possibly introduce new parameters or guidelines for this relatively new concept to ensure it is compliant with all the Sharī'ah principles and requirements.

\section{The Concept of Wa'd in the Sharī'ah} Perspective

Among the Sharī'ah contract types for Islamic financial instruments, wa'd falls under the supporting contracts. Other concepts that fall under the same category as wa'd are hiwalah, muqasah (set-off), as well as ibra'. To further understand the concept and nature of $w a^{\prime} d$, this part will be divided into several topics which are: the definition of $w a ' d$, the legality and nature of 
$w a ' d$, and some views of the jurists and scholars pertaining to the wa' $d$ mulzim (binding promise).

\section{Definition of $W a^{6} d$ :}

According to the literal meaning, wa' $d$ can be defined as a promise or undertaking. Meanwhile, currently, wa' $d$ has no technical definition of its own. However, wa'd can be defined as a commitment made by one person to another to undertake a certain actual or verbal disposal of something beneficial to the second party, or a verbal proposition made by someone to undertake something for the benefit of another person (Bank Negara Malaysia, 2013, 4; ISRA, 2011, 287).

\section{Nature and Legality of $\mathrm{Wa}^{\boldsymbol{}} \mathrm{d}$ :}

Traditionally, wa' $d$ is unilateral in nature, and binds the promisor alone. According to Bank Negara Malaysia's (BNM) guidelines on $\mathrm{wa}^{\prime} d$, $w a^{\prime} d$ is neither a contract nor an agreement. $W a^{\prime} d$ is a unilateral promise which is not binding in nature. However, a wa' $d$ contract can be binding and enforceable on the promisor if it fulfils certain requirements. In addition, according to this guideline, the binding-ness of the wa'd contract shall take effect upon the expression of the wa' $d$ by the promisor.

In fact, there are no specific verses or evidences in the Qur'ān or Hadīth detailing wa'd with respect to Islamic financial contracts. It will be up to Shari' ah scholars on how to interpret the general evidence of $w a^{\prime} d$ in both the primary sources (Bank Negara Malaysia, 2013, 11; ISRA, 2011, 287).
However, there are certain aspects in $w a ' d$ that Sharī'ah scholars have agreed upon among each other, especially regarding its general terms and conditions. For example: (i) a person must not fulfil a wa'd which includes prohibited (harām) things according to the Sharī'ah; (ii) a person needs to fulfil a wa'd which includes obligatory (wājib) things according to Sharī'ah rulings; and (iii) a person is recommended to fulfil a wa'd which includes optional (mubāh) things (Qazi, 2012, 206).

\section{Views of Scholars Pertaining to the Legitimacy of Wa'd Mulzim (Binding Promise):}

Sharī'ah scholars differ in their opinions pertaining to the extent of liability imposed upon the parties of the promise, with respect to it being either mulzim diyānatan (religious binding) or mulzim qadā'an (legally binding). Hence, this section will discuss the opinions of the Sharī'ah scholars on the binding-ness of $w a^{\prime} d$.

It is observed that the majority of Sharī'ah scholars believe that the promise made by one person to the other is mulzim diyannatan but not mulzim qadā'an. This is because wa' $d$ falls under the category of "aqd tabarr'uāt (voluntary contract). Since wa'd is part of 'aqd tabarr'uāt and is mulzim diyannatan, the court has no power to enforce the promise because the promise is only a moral obligation.

This can also be discussed based on logical thinking. For example, Person "A" promises to Person " $B$ " that " $A$ " will give " $B$ " two horses. This is considered as the 'aqd tabarr'uāt. At first, it seems like a promise, which is a unilateral 
contract. However, the nature of this contract is mubāh (optional) and according to the majority of scholars, the 'aqd tabarr' $u \bar{a} t$ is not binding. Hence, any person using the 'aqd tabarr' $u \bar{a} t$ can revoke it at any time before delivery of the gift item. Thus, it cannot be considered that $w a^{\prime} d$ is a binding contract. Among the Sharī'ah scholars with this opinion are scholars from the Hanafi, Shāfi'ì, and Hanbalī schools of thought, as well as a few from the Mālikì school of thought (BNM, 2013, 11; ISRA, 2011, 287; Qazi, 2012, 206).

It is noted that some scholars of the Sharī'ah, especially Imām Mālik and some of his followers, viewed that $\mathrm{wa}^{\prime} \mathrm{d}$ is mandatory and the promisor is legally bound to fulfil his promise even without any commitment from the other side. For example, Person "A" said to Person "B" that if "A" will travel to such a place for such a time; therefore "B" will lend to "A" a horse. Hence, once the horse has been lent to him, "A" must travel. In other words, $w a$ ' $d$ in this context is binding and it is harām (prohibited) not to fulfil it without any acceptable excuse (BNM, 2013, 11; ISRA, 2011, 287; Qazi, 2012, 206).

\section{Wa'd In Partnership-Based Sukūk Contracts}

To discuss in detail the implementation of the wa' $d$ contract, this section will first discuss sukūk, particularly the partnership-based contracts (i.e. sukūk mudāarabah and sukūk mushārikah) and how the wa'd contract applies to these sukūk.

Before we discuss in detail on the sukūk mudārabah and mushārikah, we will first look at the definition of sukūk itself to understand it more, especially the structure of the sukūk in the partnership-based contracts. Generally, the Securities Commission Malaysia defined sukūk as "a document or certificate which represents the value of an asset". Meanwhile, according to the Accounting and Auditing Organization for Islamic Financial Institutions (AAOIFI), sukūk can be defined as "a certificate of equal value representing undivided shares in ownership of tangible assets, usufruct and services or (in the ownership of) the assets of particular projects or special investment activity, however, this is true after the receipt of the value of the sukūk, the closing of subscription and the employment of funds received for the purpose for which the sukūk was issued (AAOIFI, 2010, 307)”.

\section{Wa'd In Sukūk Muḍārabah}

Generally, mudārabah is "a contract made between two parties to finance a business venture. The parties are a rabb al-māl (fund provider) or an investor who solely provides the capital and a mudārib or an entrepreneur who solely manages the project. If the venture or project is profitable, the profit will be borne solely by the provider of the capital unless the loss is caused by the mudatarib's negligence and misconduct (ISRA, 2011, 249)".

Therefore, sukūk muḍārabah can be defined as "an investment sukūk that represents the ownership of units of equal value in the mudāarabah equity, registered in the names of the sukūk holders. The sukūk holders are entitled to returns according to the percentage of their respective ownership of shares. In the sukūk 
mudāarabah, the sukūk holders are the financiers, or are known as the rabb al-māl". Usually these types of sukūk may be developed to encourage wide public participation. In addition, the sukūk holder, or the subscriber, is the rabb al-māl. The mudārib, also known as the entrepreneur, may be an investment company or a special purpose vehicle (SPV) that is formed to manage the securities and carry out the business projects (Hassan, 2013, 265).

\section{Structure of the Sukūk Muḍarabah:}

It is noted that this part will only discuss the basic structure of the sukūk mudārabah because this research will focus more on the Sharī'ah issues of the wa'd mulzim in partnership-based sukūk contracts. Hence, this part will explain the brief structure of the sukūk mudārabah and some general terms and conditions applied to the sukūk muḍārabah.

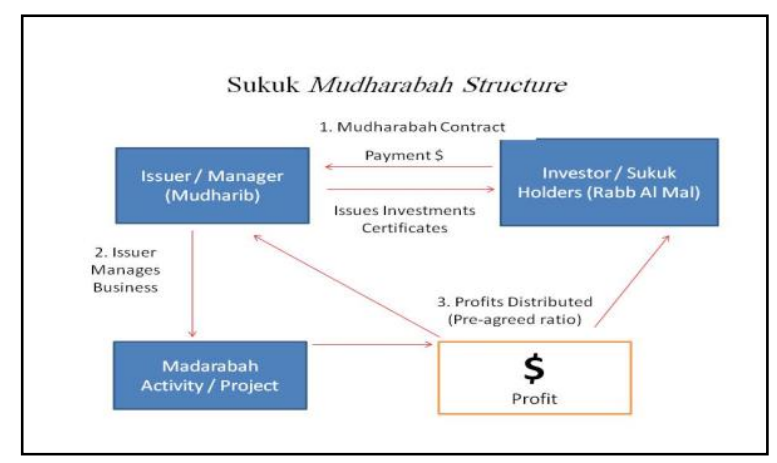

According to the above structure, the investor/sukūk holder will form the sukūk mudārabah contract with the issuer/manager. Then the issuer or manager will manage the business or invest in any Sharī‘ah compliant project. The profit will be divided and shared according to the earlier pre-agreed contract. If there are losses, they will be borne by the investor or sukūk holder unless the losses were caused by the muḍarib's negligence or misconduct (ISRA, 2011, 425; Hassan, 2013, 267).

\section{General Terms and Conditions of the Sukūk \\ Mudārabah:}

The terms and conditions of the sukūk

mudārabah are as follows:

i. Capital will be from the rabb al-māl

ii. Mudārib will manage the projects / activities.

iii. The profit will be divided according to the pre-agreed ratio.

iv. Losses (if any) will be borne by the rabb $a l-m \bar{a} l$ unless the loss was caused by the mudārib's negligence or misconduct.

v. Mudārib cannot guarantee rabb al-māl's capital unless it is guaranteed by the third party. vi. The projects or investments activities should be permissible and in compliance with Sharī‘ah principles.

Hence, from the above general terms and conditions, particularly on the guaranteed capital, it will result in the issue of the application of wa'd to guarantee the mudārib's capital. Is the application of wa'd mulzim to guarantee the mudārib's capital permissible according to Sharī'ah requirements? Is it permissible in Sharī'ah for the rabb al-māl to purchase the sukūk muḍārabah from the rabb al-māl, or vice versa?

This issue will be discussed in detail in the next part on the Sharí'ah issues of wa'd mulzim in partnership-based sukūk contracts. 


\section{Wa'd in Sukūk Mushārakah}

The word "mushārakah" refers to "a partnership arrangement between two parties or more to finance a business venture whereby all parties contribute capital either in the form of cash or other forms. Any profit derived from the venture is distributed based on a pre-agreed profit sharing ratio and a loss is shared on the basis of the capital contribution (ISRA, 2011, 244). Sukūk mushārakah is "a partnership certificate used for raising capital to widen the partnership net of the investment, where all the participants or partners share the risks and rewards". Generally, sukūk mushārakah is similar to sukūk mudārabah (Hassan, 2013, 268).

Any Sharī‘ah rules that apply to the sukūk muḍārabah also apply to the sukūk mushārakah. However, it has some differences, especially in the profit and loss sharing. As mentioned earlier, in the sukūk mudârabah, profit will be shared according to the pre-agreed profit sharing ratio and the loss will borne by the rabb al-māl itself. Meanwhile, in the sukūk mushārakah, the profit will also be shared according to the pre-agreed ratio, but the loss is shared on the basis of equity participation.

Moreover, in the sukūk mushārakah transaction, both the issuer and investor may contribute to the capital of the mushärakah project. The project is normally managed by either the issuer itself or through appointing a third party agent. In the case of the project being managed by a third party, this structure is classified as a sukūk wakālah bi istithmār (investment agency sukūk) (ISRA, 2011, 428).

\section{Structure of the Sukūk Mushārakah:}

To facilitate better understanding, below is an example of the structure for the sukūk mushārakah (ISRA, 2011, 428; Hassan, 2013, 268).

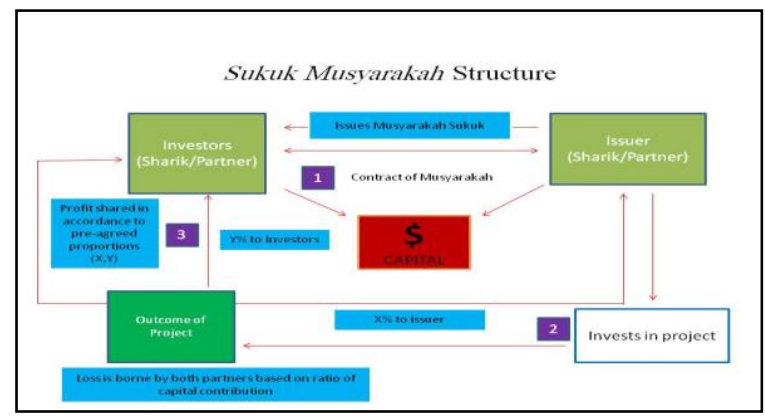

General Terms and Conditions of the Sukūk Mushārakah:

The terms and conditions of the sukūk mushārakah are as follows:

i. The profit will be divided between all the partners according to the pre-agreed ratio.

ii. The proportion of losses borne by partners must be commensurate with the proportions of their contributions to the capital.

iii. The business or the projects carried out by partners should be permissible and in compliance with Shari'ah requirements. The purpose of the projects must not be prohibited in Islam.

As mentioned in the sukūk mudārabah, the Sharī'ah issues regarding the sukūk mushārakah also concerns the capital guaranteed by other partners. In addition, is it permissible in accordance with Sharī'ah requirements to sell the sukūk mushārakah to the other partners, or purchase from them? 


\section{Sharī'ah Issues of $\mathrm{Wa}^{`} \mathrm{~d}$ Mulzim in}

Partnership-Based Sukūk Contracts

The implementations of the wa'd contracts in Islamic financial products have raised issues and discussion among Sharī‘ah scholars. It is observed that wa'd mulzim is more suitable for sukūk contracts. Hence, this section will discuss further the Sharī'ah issues in the implementation of $w a^{\prime} d$ contracts and the solutions to ensure permissibility according to Sharī $`$ ah.

In fact, in the partnership-based contracts, i.e. mudāarabah and mushārakah, there will be common issues, which are certainty of return, as well as certainty of the capital. Usually, in the partnership-based contracts, the mudārib cannot promise or guarantee the capital and the profit of the rabb al-māl. Similarly, in the mushārakah contract, the sharik or partner cannot guarantee the other partners the profit and the capital. However, if a third party guarantees the capital, this is permissible according to Sharī'ah requirements.

\section{Certainty of Return:}

As for certainty of return, in the partnershipbased sukūk contracts, the third party usually promises to fund the projects or investments if any shortfall occurs. A formal liquidity facility arrangement is used to achieve certainty of return. Hence, the deficit in the projects will be funded by the third party. In addition, if there is any surplus, or if the profit is higher than the expected return, the excess or surplus will be given to that third party as an incentive fee (ISRA, 2011, 432). That incentive fee is another
Sharī'ah issue and will be discussed in the next section.

\section{Certainty of Capital:}

Meanwhile, as for certainty of capital, an unconditional purchase undertaking at par is used to achieve the effect. Unconditional means regardless of the performance of the venture, the obligor or the third party will have to buy the assets or interest in the venture if the investors exercise the purchase undertaking.

In other words, the mudāarib or the partner promises to purchase the sukūk from the issuer, or the issuer promises that it will sell its interest in the sukūk to the mudāarib or the shārīk, either upon maturity of the assets or interest, or in the event of a default. From this point of view, the purchase of the assets or interest of the sukūk is also similar to the issuance of the third-party guarantee of the capital. Hence, wa' $d$ contracts, particularly wa'd mulzim contracts, have been applied to purchase the assets or interest of the investors (ISRA, 2011, 432).

\section{Sharī'ah Solutions}

To ensure that the transactions are permissible according to the Sharī'ah requirements, there are certain terms and conditions that need to be applied in order to avoid any non-compliance issues. One of the suggestions is by using $\mathrm{wa}^{\prime} \mathrm{d}$ mulzim contracts. However, wa'd mulzim contracts also require certain conditions in order to not contravene with the Sharī'ah requirements.

Below are the opinions of related organizations or regulatory bodies explaining the terms and conditions of the $w a$ ' $d$ : 


\section{a) Accounting and Auditing Organization}

\section{for Islamic Financial Institutions:}

According to the International Sharī‘ah Research Academy for Islamic Finance (ISRA), their book titled "Islamic Financial System; Principles \& Operations" stated that from the decisions made by the Sharīalah body of the Accounting and Auditing Organization for Islamic Financial Institutions (AAOIFI), a wa'd which is mulzim in nature made by both parties is like a contract or ' $a q d$. The differences between a promise made by one party and the promise made by two parties are as follows:

i. If the promise is made by one party, then the promise will be considered as "mulzim diyānatan" upon the promisor. The ruling for such an instance is that the promisor must carry out his promise if such a promise is related to a specific reason that would require commitment to the promise.

ii. A promise made by both parties, i.e., almuwa'adah is permissible but it is not mulzimah (binding) in nature upon both parties, because if the muwa'adah is mulzimah in nature, it is synonymous to an 'aqd (ISRA, 2011, 288).

\section{b) Ruling by OIC Islamic Fiqh:}

Meanwhile, the book also stated the latest ruling made by the OIC Islamic Fiqh, in its 17th meeting:

i. A mulzim promise made by both parties is originally mulzim diyānatan (religiously binding) and not mulzim qadā'an (legally binding).

ii. A mulzim (binding) promise by both parties in contracts like 'inah and salaf transactions is a trick to permit riba (interest) and is prohibited by Sharī‘ah. iii. It is permitted in a situation where a sale and purchase transaction cannot be performed because the seller does not possess the object of sale, but there is public need to ensure that both parties perform the contract in the future based on the provision of law or by mutual consent of both parties.

iv. A promise by both parties as mentioned in paragraph (iii) does not consider the future transaction; therefore, the ownership of the subject matter will not transfer to the buyer. The sale and purchase will only be executed at the time agreed by both parties after the completion of $i j a \bar{a} b$ (offer) and qabūl (acceptance).

v. For the situation mentioned in paragraph (iii), if one of the parties breaks the promise, he is legally bound to fulfil the contract or to remove the hardship which is borne by both parties due to the breach of the contract (ISRA, 2011, 289).

In addition, the Resolution of the International Islamic Fiqh Academy of the OIC in its fourth session in 1988 also stated that the sukūk muḍarabah participants are given the right to transfer the ownership by selling the sukūk in the securities market at their discretion. The market value of muqāraḍah sukūk varies with the business status and anticipated or expected profits of the concerned project. The sale must follow the rules listed below:

i. If the mudārabah capital is still in the form of money before the operation of the specific project, the trade will be akin to the exchange of money for money and must satisfy the rules of bay'al-sarf(currency exchange contract). 
ii. If the mudarabah capital is in the form of debt, it must be based on the principles of bay ${ }^{6} a l$ dayn (debt trading).

iii. If the capital is in the form of a combination of cash, receivables, goods, real assets, and benefits, the trade must be based on the market price evolved by mutual consent (Islamic Fiqh Academy, 2000, 63).

In addition, from this point of view, since the mudārabah and mushārakah concepts are under partnership-based contracts and the features of both mudārabah and mushārakah are almost similar except in the event of loss, the above rulings are also applicable for the mushārakah based contract.

\section{c) Bank Negara Malaysia (BNM)}

According to the guidelines of $w a$ ' $d$ by BNM, the muḍārib may enter into a binding wa'd to purchase the underlying mudārabah or mushārakah business upon maturity, dissolution, or in the event of default. In addition, the requirements of a binding $w a ' d$ are as follows:

i. A $w a^{\prime} d$ shall be a binding $w a^{\prime} d$ if it is linked with a specific cause or specified event, and the promise will incur expenses because of action or refraining from action in reliance upon the $w a$ ' $d$.

ii. A fee shall not be imposed on a wa'd (BNM, 2013, 1-14).

Hence, from the above statement, it is observed that wa'd mulzim can be applied, but with certain conditions that need to be observed. Thus, from this point of view, it is permissible to use the $w a^{\prime} d$ contract, particularly wa'd mulzim, in the event of the muḍārib or the shärīk promising to purchase the sukūk from the issuer; or the issuer promising that it will sell its interest in the sukūk to the mudāarib or the shārīk, either upon maturity of the assets or interest, or in the event of a default

In addition to the above justification, a muḍārabah or mushārakah contracts may be arranged with a promise ( $w a d^{\prime} d$ ) where:

a) A muḍārib or partner undertakes to purchase a mudārabah asset/form, or to sell his share to other partners upon the occurrence of a specified event as stipulated in the mudatrabah contract; or

b) An agent (wakīl) appointed by a muḍārib undertakes to purchase a mudārabah asset or to purchase or sell the underlying asset of the mushärakah upon the occurrence of a specified event as stipulated in the mudārabah or mushārakah contract.

Pursuant to the above justification, the price shall not be based on the face/par value of the underlying muḍārabah and mushārakah business or projects. The purchase price may be based on market value, fair value, or any price to be agreed upon by the parties at the time of purchase (BNM, 2015, 16).

Meanwhile, on the issue of certainty of the return or profit, as mentioned earlier, profit cannot be guaranteed, especially in the event of loss or guaranteeing a profit return at a fixed price. However, it is permissible if the guarantor is a non-related party or third party. In fact, third party guarantee is allowed from the Sharī'ah point of view as long as the third party has no direct relation to the interest of the sukūk. The issue of capital protection has been a longrunning one in the sukuk contracts since most 
available third parties would charge a fee for the guarantee or recovery of the capital, as practiced by agencies such as Dana Jamin. Sukūk mushārakah will be shared between partners/investors as pre-agreed and proportionate to the portions of the contributions of the partners/investors. The AAOIFI, 7/6 stated that: "It is permissible for a third party other than the mudataib or investment agent or one of the partners, to undertake voluntarily that he will compensate the investment losses of the party to whom the undertaking is given, provided that this guarantee is not linked in any manner to the mudārabah financing or investment agency contract".

In addition, the bank also can apply a Profit Equalisation Reserve (PER) as a mitigation tool if there are any shortfalls in the investments activities. Under the PER mechanisms, the bank is allowed to take any extra profit from the investments activities and will give only the expected return to the customer.

It is also one of the conditions stipulated in the requirements of the mudārabah contracts. Besides that, the bank is not required to give the extra profit under the PER fund to the customer. However, it also needs to be stated that the extra profit under the PER fund does not belong to the bank. It belongs to the customers, as a mitigation tool if there are any shortfalls (BNM, 2015, 14). The Resolution of the International Islamic Fiqh Academy of the OIC in its fourth session in 1988 stated that it is permissible to create reserves for contingencies, such as loss of any capital, by deducting a certain percentage from the profit or return in each accounting period (Islamic Fiqh Academy, 2000, 63-64).

Meanwhile, on the issue of the incentive fees, AAOIFI states in its Sharī'ah Standard No. 13 , Clause $8 / 2$, apart from the agreed proportion of the profit as determined in the above manner, the muda rib cannot claim any periodical salary or a fee or remuneration for the work done by him. However, it is permissible for the two parties to construct a separate agreement independent of the mudârabah contract, assigning one party to perform, for a fee, a business activity that is not by custom part of the mudārabah operations (AAOIFI, 2010, 237).

\section{Conclusion}

In the end, Islamic financial contracts are structured based on the categories of the contracts. The sukūk also can be classified according to several types, namely tradable sukūk, non-tradable sukūk, equity-based sukūk, and debt-based sukūk. Sukūk muḍārabah and sukūk mushārakah fall under the category of equity-based sukūk, also known as partnershipbased types of sukūk. In other words, equitybased sukūk are partnership-based Islamic investment certificates of partnership contracts where the parties share the profits as well as any risk arising from the investment activity. Sukūk mudāarabah refers to investment certificates that represent the ownership of units of equal value in the equity of trust financing investment and are registered in the name of the holders. Sukūk mushärakah refers to partnership certificates used for rising capital to widen the partnership 
net of investment, where all the participants or partners share the risks and rewards or profits.

In addition, in this sophisticated world, sukūk is one of the most important elements in the Islamic banking and finance industry. The Islamic financial industry needs to develop and provide a suitable and competitive alternative to replace conventional bonds that yield ribō (interest), which are prohibited by Islamic law in transactions. Thus, sukūk is a very suitable instrument that complies with Sharī'ah requirements and principles.

To ensure that the sukūk instruments are compliant with Sharī'ah requirements, it is very important that all the relevant key players in the Islamic banking and finance industry play their important roles to develop Islamic products or to enhance the products to become suitable for the masses, especially Islamic societies. As discussed in this article, wa' $d$ contracts have become the most important part in sukūk based products. However, it needs to be examined and researched to justify it as per Sharī'ah requirements. It is suggested that in order to ensure a $w a$ ' $d$ contract is permissible from the Sharī ah perspective, participants should construct wa'd contracts which are separate from the sukūk contracts, according to the terms and conditions explained in this article. Thus, the prohibited elements in Sharī'ah can be avoided.

Besides that, it bears reminding that there are two regulatory bodies in Malaysia that have been appointed to ensure and observe that all the Islamic financial products are in accordance with the Sharī'ah, which are Bank Negara Malaysia (BNM) and the Securities Commission (SC).
BNM's role leans more towards Islamic banking products, particularly in asset-based and depositbased contracts. Meanwhile the Securities Commission is more responsible for the sukūk industry. This article has been done by referring more to the parameters, guidelines, or circulars imposed by BNM towards basic Islamic contracts, such as mudāarabah and murābahah. However, those references are also related and can be referred to as secondary references on the issues of sukūk. It is also noted that the issues related to the sukūk contracts will be observed and decided by the Sharī'ah Committees of the Securities Commission itself. Finally, it is also important that the parameters or guidelines for the Shariah issues applied to the sukūk contracts act as a clear guide to the key players in Islamic banking and finance.

\section{References}

Abdullah, J. \& Mahmud, M. (2008). "Penggunaan Wa'd dalam Kontrak Buyu', Ijarah dan Syirkah Dari Perspektif Industri”, Muzakarah Cendekiawan Syariah Nusantara, Februari 2728.

Accounting and Auditing Organisation for Islamic Financial Institutions (AAOIFI). (2010). "Shari'a Standards for Islamic Financial Institutions". Bahrain: AAOIFI.

Al-Bukhari, Muhamamd Ismail. Sahih Al-Bukhari. N. C.: Dar Ibn Kathir, no. of hadith: 33: Bab 'Alamat al-Munafiq.

Al-Ghazali, Abu Hamid Muhammad. Ihya Ulum alDin. Egypt: Al-Maktabah al-Tijariyyah alKubra.

Al-Masri, R. Y. (2002). The Binding Unilateral Promise (Wa'd) in Islamic Banking Operations: Is it Permissible for a Unilateral Promise ( $\left.W a^{\prime} d\right)$ to be Binding as an Alternative to a Proscribed Contract?. Journal of King Abdul Aziz University. Volume 15, pp 29-33. 
Al-Qarafi, Shihab al-Din Abi Al-Abbas Ahmad ibn Idris ibn Abd Rahman al-Shanhaji. Al-Furuq. Beirut: 'Alam al-Kutub.

An-Nawawi, Muhyi al-Din Abu Zakaria Yahya ibn Sharif al-Dimashqi al-Shafi i. (1988) AlAdhkar al-Muntakhabah min kalam Sayyid alAbrar. Beirut: Dar al-Din li al- Turath.

Bank Negara Malaysia (BNM). (2010). "Shariah Resolutions in Islaimc Finance." Kuala Lumpur, Second Edition.

Bank Negara Malaysia. "Guidelines on Profit Equalisation Reserve”.

Bank Negara Malaysia. (2015). “Mudarabah.” BNM/RH/STD 028-8, issued on: 20 April 2015.

Bank Negara Malaysia. (2015). “Musyarakah.” BNM/RH/STD 028-7, issued on: 20 April 2015.

Bank Negara Malaysia. (2013). “Wa'd (Shariah Requirements and Optional practices) Exposure Draft." BNM/RH/CP 028-6, issued on: 09 December 2013.

Hassan, A. (2008). Pengertian Al-Wa'd, Al-Wa'dan dan Al-Muwa'dah. Muzakarah Cendekiawan Syariah Nusantara. Februari 27-28.

Ibn Hazm, Abu Muhammad Ali ibn Ahmad ibn Said. Al-Muhalla. Beirut: Dar al-Afaq al-Jadidah.

International Shariah Research Academy for Islamic Finance (ISRA). (2011). "Islamic Financial System; Principles \& Operations.” Kuala Lumpur.

Islamic Fiqh Academy. (2000). "Resolutions and Recommendations of the Council of The Islamic Fiqh Academy 1985-2000." Jeddah: Islmamic Research and Training Institute Islamic Development Bank, First Edition.

Lukman, B. (2008). Penggunaan Wa'd Dalam Kontrak Buyu', Ijarah dan Syirkah: Adakah Aplikasi Wa'd boleh Menjejaskan Kontrak Kewangan. Muzakarah Cendekiawan Syariah Nusantara. Februari 27-28.

M. Kabir Hassan, Rasem N. Kayed, Umar A. Oseni. (2013). "Introduction to Islamic Banking \& Finance." England: Pearson Education Limited, First Edition.

Mushtaq Ahmad Qazi. (2012). "The Binding Nature of Wa'd (Promise) and its Application in Islamic Finance”, International Journal of Business and Social Science, Vol. 3, No 4.

Yahya, A.S. (2008). Penggunaan Wa'd dalam Kontrak Buyu', Ijarah dan Syirkah: Implikasi Hukum. Muzakarah Cendekiawan Syariah Nusantara. Februari 27-2. 